\title{
Os Benguelas de São João del Rei: tráfico atlântico, religiosidade e identidades étnicas (Séculos XVIII e XIX) *
}

\author{
Silvia Brügger** \\ Anderson de Oliveira***
}

O presente artigo visa discutir de forma articulada questões relacionadas ao tráfico atlântico, à religiosidade e à constituição de identidades étnicas na sociedade escravista brasileira, na virada do século XVIII para o XIX. Para tanto, centrando nossa abordagem na região de São João del Rei, inicialmente apresentamos uma visão geral dos diversos grupos étnicos ali presentes e, posteriormente, focamos a análise nos benguelas. Estudando as estratégias de formação de identidades coletivas do grupo em questão, procuramos avançar na compreensão do tráfico atlântico como um elemento decisivo na formação sociocultural da América Portuguesa. Tomamos como fontes principais os registros paroquiais de óbito e a documentação da Irmandade de Nossa Senhora do Rosário de São João del Rei.

Palavras-chave: Tráfico Atlântico - Religiosidade - Identidade Étnica

* Artigo recebido em junho de 2007 e aprovado para publicação em setembro de 2007. Este artigo é um dos resultados de um projeto coletivo de pesquisa financiado pela Fundação de Amparo à Pesquisa do Estado de Minas Gerais - FAPEMIG.

** Professora Adjunta do Departamento de História da Universidade Federal de São João Del Rei. E-mail: sbrugger@oi.com.br.

*** Professor Adjunto do Instituto de Aplicação da Universidade do Estado do Rio de Janeiro e Professor Titular das Faculdades Integradas Campo-Grandenses. E-mail: anderclau@ alternex.com.br. 
The Benguelas of São João del Rei: Atlantic trade, religiosity and ethnic identities in the Eighteenth and Nineteenth Centuries

The objective of the present article is to discuss questions related to Atlantic trade, religiosity and the construction of ethnic identity in Brazilian slave society during the period the $18^{\text {th }}$ and $19^{\text {th }}$ centuries. Here, we have chosen to focus our analysis on the São João Del Rei region. First, we present a general view of the diverse ethnic groups inhabiting the region, following with a more focused analysis of the Benguelas group. Looking at the formation strategies of Benguelas collective identity, we try to advance in our comprehension of the Atlantic slave trade as a decisive element in the social and cultural formation of Portuguese America. Our principal sources are parish death registers and documents of the Nossa Senhora do Rosário brotherhood from São João Del Rei.

Keywords: Atlantic trade - Religiosity - Ethnic Identity

Les Benguelas de São João del Rei: traite atlantique, religiosité et identités ethniques (XVIII ${ }^{\mathrm{e}}$-XIX ${ }^{\mathrm{e} \text { èmes }}$ Siècles)

Cet article a pour but de présenter un débat cohérent au sujet de la traite atlantique des esclaves, de la religiosité et de la constitution des identités ethniques dans la societé esclavagiste brésilienne, aux dernières années du XVIII ${ }^{m e}$ siècle et à la première moitié du XIX ${ }^{\text {ème }}$ siècle. L'approche est centrée dans la région de São João del Rei. D’abord on donne une vision générale de plusiers groupes ethniques existants dans cette région, pour ensuite analyser spécifiquement l'ethnie benguela. Il s'agit d'étudier les stratégies de formation des identités colletives des benguelas et d'avancer dans la compréhension de la traite atlantique comme un élément fondamental dans la formation sociale et culturelle de l'Amérique Portugaise. Les sources principales sont les registres paroissiaux de décès et la documentation de la Confrérie de Notre Dame du Rosaire à São João del Rei.

Mots-clés: Traite Atlantique - Religiosité - Identitté Ethnique

Procuramos, neste artigo, analisar a procedência de cativos e libertos, em São João del Rei, na virada do século XVIII para o XIX, relacionando tal fator à dinâmica do tráfico atlântico de cativos e ao processo de constituição de identidades étnicas na região. Tomamos como fontes principais para a análise os registros paroquiais de óbito e a documentação da Irmandade de Nossa 
Senhora do Rosário de São João del Rei. Partimos inicialmente de uma visão geral dos diversos grupos étnicos, para posteriormente, enfatizando a questão da religiosidade, focarmos a análise nos benguelas de São João del Rei. Desde a afirmação de Roberto Martins ${ }^{1}$ da relevância do contingente mancípio de Minas Gerais, no século XIX, muito se tem discutido na historiografia sobre a origem da população cativa: seria ela tributária do tráfico negreiro - como indicam, por exemplo, os trabalhos do próprio Martins ${ }^{2}$ e os dados de João Fragoso e Roberto Guedes Ferreira ${ }^{3}$ - ou resultante do crescimento natural como sugere Bergad. ${ }^{4}$ Com Libby, entendemos que é na análise regional que se podem buscar resultados mais consistentes para a questão. ${ }^{5}$ Assim, procuramos analisar a região de São João del Rei, em um período que foi caracterizado como de acomodação evolutiva de sua economia; ${ }^{6}$ ou seja, momento em que a atividade mineradora havia declinado e a produção de abastecimento e o comércio preexistentes assumiram progressivamente a posição de carro-chefe econômico.

Inicialmente, tomaremos como fonte os registros paroquiais de óbito assentados em livros da Matriz de Nossa Senhora do Pilar de São João del Rei, que, em geral, informam a procedência dos falecidos. Ao utilizar esta fonte, pretendemos evitar problemas inerentes a outros documentos para análise desta questão, como, por exemplo, os registros paroquiais de batismo - sujeitos a deturpações provocadas por possíveis padrões diferenciados de fecundidade das mulheres de distintos grupos étnicos - ou os inventários post-mortem,

${ }^{1}$ Roberto Borges Martins, A economia escravista de Minas Gerais no século XIX, BH: CEDEPLAR/FALE/UFMG, 1980, Coleção Textos para Discussão, v. 10.

${ }^{2}$ Ibidem; Roberto Borges Martins, "Minas Gerais, século XIX: tráfico e apego à escravidão numa economia não-exportadora”, Estudos Econômicos, XIII, n. 1, 1983.

${ }^{3}$ João Luís Fragoso e Roberto Guedes Ferreira, "Alegrias e artimanhas de uma fonte seriada. Os códices 390, 421, 424 e 425: despachos de escravos e passaportes da Intendência de Polícia da Corte, 1819-1833", in: Tarcísio R. Botelho e outros (org.), História Quantitativa e Serial no Brasil: um balanço, Goiânia, ANPUH-MG, 2001.

${ }^{4}$ Laird W. Bergad, Escravidão e História Econômica - Demografia de Minas Gerais, 1720-1888, Bauru, EDUSC, 2004.

${ }^{5}$ Douglas C. Libby, "Minas na mira dos brasilianistas: reflexões sobre os trabalhos de Higgins e Bergad", in: Tarcísio R. Botelho e outros (org.), op. cit.

${ }^{6}$ Carla M. Carvalho de Almeida, "Minas Gerais de 1750 a 1850: bases da economia e tentativa de periodização", LPH - Revista de História, Departamento de História da UFOP, n. $5,1995$. 
sujeitos, segundo Libby, a extravios dos arquivos. ${ }^{7}$ É claro que também os assentos de óbito podem apresentar sub-registros. Entendemos, porém, que, devido ao valor escatológico dos sacramentos ministrados ao moribundo, à importância dos legados pios e ao caráter de efeito civil deste documento, não deveria ser comum a prática de se deixar de assentar os óbitos. Isso não significa que se está, necessariamente, trabalhando com a totalidade de falecimentos da região. Aliás, nos próprios documentos coletados para São João del Rei, inexistem registros para os anos de 1815, 1816 e 1817, indício claro de que os mesmos se perderam. Essas perdas, porém, não parecem deturpar a análise dos dados apresentados, pois não temos razão para supor que teria atingido preferencialmente um segmento específico da população.

Outro ponto para o qual se deve atentar, nos registros de óbito, é que obviamente eles refletem ingressos e/ou nascimentos de cativos ocorridos em períodos anteriores. Isso, porém, é válido também para os inventários post-mortem. Quanto aos registros de batismo, ao se considerar os batizados de adultos, tem-se uma percepção das procedências dos cativos em determinado momento. No entanto, sabe-se que nem todos os africanos eram batizados em seu destino final, em Minas Gerais. Muitos o eram ainda em território africano, nos navios negreiros e nos portos de desembarque. Portanto, esses dados tendem a ser menos consistentes do que os óbitos, o que não significa que não possam funcionar como uma indicação do ingresso de escravos na região.

Ao todo, foram coletados 12.835 registros de óbito para o conjunto da população de São João del Rei. É interessante notar que os livros de registros paroquiais da Matriz de Nossa Senhora do Pilar anotavam, diferentemente do que previam as Constituições Primeiras do Arcebispado da Bahia, conjuntamente assentos da população livre, cativa e liberta. Este fato facilita a coleta dos dados para o conjunto da população, viabilizando comparações e análises mais completas.

A Tabela 1 apresenta a distribuição dos assentos segundo a condição social dos falecidos.

\footnotetext{
${ }^{7}$ Segundo Libby, em busca dos inventários de grandes proprietários escravistas da Freguesia de São José, identificados nominalmente no Rol dos Confessados daquela freguesia, pouquíssimos foram localizados. O autor infere que as famílias da elite mineira conseguiam, muitas vezes, ficar de posse desses documentos, ao invés de deixá-los nos cartórios. Como os grandes proprietários tendencialmente deveriam ser os maiores detentores de africanos, análises feitas a partir deste tipo de fonte podem estar sujeitas a deturpações. Cf. Douglas C. Libby, op. cit., p. 296.
} 


\section{Tabela 1 - Condição dos Falecidos - 1782 a $1822^{\#}$}

\begin{tabular}{|l|r|r|}
\hline Condição do Falecido & No. & $\%$ \\
\hline Escravos & 5.421 & $42,2 \%$ \\
\hline Forros & 959 & $7,5 \%$ \\
\hline Livres & 6.455 & $50,3 \%$ \\
\hline Total & 12.835 & $100,0 \%$ \\
\hline
\end{tabular}

Fonte: APNP (Arquivo da Paróquia de Nossa Senhora do Pilar de São João del Rei). Registros Paroquiais de Óbitos - Matriz de Nossa Senhora do Pilar de São João del Rei - 1782-1807.

*Não existem registros para os anos 1815,1816 e 1817.

Os dados acima comprovam a importância da população cativa na região. É interessante, porém, notar que o seu peso no conjunto da população diminuiu ao longo do período (Tabela 2).

\section{Tabela 2 - Condição dos Falecidos por décadas}

\begin{tabular}{|c|c|c|c|c|c|c|c|c|c|c|}
\hline $\begin{array}{l}\text { Período } \\
\text { Condição }\end{array}$ & \multicolumn{2}{|c|}{$1782-1790$} & \multicolumn{2}{|c|}{$1791-1800$} & \multicolumn{2}{|c|}{$1801-1810$} & \multicolumn{2}{|c|}{$1811-1820^{\#}$} & \multicolumn{2}{|c|}{$1821-1822$} \\
\hline Escravos & 1.043 & $52,5 \%$ & 2.136 & $45,9 \%$ & 1.640 & $35,7 \%$ & 489 & $37,5 \%$ & 113 & $38,1 \%$ \\
\hline Forros & 213 & $10,7 \%$ & 300 & $6,4 \%$ & 357 & 7,8 & 75 & & 14 & $4,7 \%$ \\
\hline Livres & 731 & $36,8 \%$ & 2.223 & $47,7 \%$ & 2.593 & 56,5 & 738 & $56,7 \%$ & 170 & $57,2 \%$ \\
\hline Total & 1.987 & $100,0 \%$ & 4.659 & $100,0 \%$ & 4.590 & $100,0 \%$ & 1.302 & $100,0 \%$ & 297 & $100,0 \%$ \\
\hline
\end{tabular}

Fonte: APNP. Registros Paroquiais de Óbitos - Matriz de Nossa Senhora do Pilar de São João del Rei - 1782-1807.

"Não existem registros para os anos 1815, 1816 e 1817.

A queda do percentual de cativos no conjunto da população se deu de forma mais incisiva na primeira década do século XIX, refletindo talvez um momento anterior de instabilidade com a crise da mineração e o progressivo processo de afirmação de uma economia mercantil de abastecimento. ${ }^{8}$ Os anos seguintes indicam uma tendência à retomada do crescimento do contingente mancípio, embora em níveis inferiores aos das últimas décadas do século XVIII.

\footnotetext{
${ }^{8}$ Conforme argumentado na tese de doutorado de Silvia Brügger, se hoje sabemos que a crise da mineração não levou a uma involução econômica da Capitania/Província de Minas Gerais, esse saber não era o mesmo por parte dos agentes históricos que vivenciaram tal processo. Assim, a autora entende que diversas variáveis demográficas sofreram influência, sobretudo, na década de 1780, de um clima de certa instabilidade econômica. Parece-nos que o declínio da população mancípia, no início do século XIX, pode refletir uma diminuição de ingressos de novos cativos nas últimas décadas dos setecentos. Sobre as demais variáveis demográficas, cf. Silvia Maria J. Brügger, Minas Patriarcal-Família e Sociedade (São João del Rei, séculos XVIII e XIX), Tese de Doutorado, Niterói, UFF, 2002.
} 


\section{Procedência dos Escravos}

O primeiro aspecto a ser analisado sobre a procedência dos cativos diz respeito à proporção de nascidos na África ou na América Portuguesa.

\section{Tabela 3 - Origem dos Escravos - 1782 a 1822"}

\begin{tabular}{|c|c|c|}
\hline Procedência & No. & $\%$ \\
\hline África & 2.535 & $46,8 \%$ \\
\hline América Portuguesa & 824 & $15,2 \%$ \\
\hline S/Referência & 2.058 & $38,0 \%$ \\
\hline Total & 5.421 & $100,0 \%$ \\
\hline
\end{tabular}

Conforme os dados da Tabela 3, pode-se constatar que predominavam entre escravos falecidos os de procedência africana. No entanto, chama a atenção a grande proporção de cativos falecidos cuja procedência não foi informada no registro. Constatamos, porém, que a maioria desses últimos registros referia-se a crianças (1.277, em um total de 2.058), indicadas por termos como "inocente" e "recém-nascido", ou por idades até onze anos.9 Já dentre os indicados como nascidos na América Portuguesa, apenas uma minoria era de crianças (53, em um universo de 824). Assim, partindo do pressuposto de que a grande maioria das crianças era, sem dúvida, nascida na colônia, pode-se inferir um equilíbrio maior entre "africanos" e "crioulos" do que o mostrado pelas proporções indicadas na Tabela 3. Por outro lado, infere-se também que a força de trabalho cativa era majoritariamente africana. ${ }^{10}$ Assim, parece-nos mais correta a afirmação de que a reprodução da escravidão dependia, nesse caso, tanto da reprodução natural como do tráfico; porém, é inegável a importância dos africanos para a constituição da força de trabalho.

É interessante observar como esses índices variaram no decorrer do período.

\footnotetext{
${ }^{9}$ Marcelo Assis, trabalhando com registros de óbito das freguesias de Saquarema e São José, no Rio de Janeiro, entre 1790 e 1830, também encontrou essa tendência à omissão da referência à condição de crioulo para as crianças. Cf. Marcelo Ferreira Assis, Tráfico atlântico, impacto microbiano e mortalidades escrava, Rio de Janeiro, c.1790-c.1830, Dissertação de Mestrado, Rio de Janeiro, UFRJ, 2002.

${ }^{10}$ Se compararmos o número de crianças batizadas, em São João del Rei, entre 1780 e 1820, e o número de óbitos infantis registrados, teremos que enquanto nasceram 8.355 , faleceram 1.301; ou seja, cerca de 15,5\% daquele universo. Para os batismos, cf. Silvia Maria J. Brügger, op. cit., p. 83 .
} 


\section{Tabela 4 - Origem dos Escravos por décadas}

\begin{tabular}{|c|c|c|c|c|c|c|c|c|c|c|}
\hline $\begin{array}{r}\text { Período } \\
\text { Procedência }\end{array}$ & \multicolumn{2}{|c|}{$1782-1790$} & \multicolumn{2}{|c|}{$1791-1800$} & \multicolumn{2}{|c|}{$1801-1810$} & \multicolumn{2}{|c|}{ 1811-1820\# } & \multicolumn{2}{|c|}{$1821-1822$} \\
\hline África & 598 & $57,3 \%$ & 1017 & $47,6 \%$ & 729 & $44,5 \%$ & 159 & $32,6 \%$ & 32 & $29,1 \%$ \\
\hline América Portuguesa & 112 & $10,7 \%$ & 295 & $13,8 \%$ & 304 & $18,5 \%$ & 100 & $20,5 \%$ & 13 & $11,8 \%$ \\
\hline S/Referência & 334 & $32,0 \%$ & 824 & $38,6 \%$ & 607 & $37,0 \%$ & 229 & $46,9 \%$ & 65 & $59,1 \%$ \\
\hline Total & 1.044 & $100,0 \%$ & 2.136 & $100,0 \%$ & 1.640 & $100,0 \%$ & 488 & $100,0 \%$ & 110 & $100,0 \%$ \\
\hline
\end{tabular}

Fica nítido, na Tabela 4, o declínio da proporção de africanos e o aumento dos cativos nascidos na América Portuguesa. À exceção dos últimos dois anos, o percentual de crioulos vinha crescendo e, talvez, o declínio em 1821-22 reflita apenas uma certa inconsistência dos dados para um período tão curto. Por outro lado, os escravos falecidos que não tiveram referências a seus locais de nascimento e/ou procedência também registraram crescimento significativo. A mantermos o raciocínio apresentado na análise da Tabela 3 , pode-se concluir que vinha em processo de expansão a população cativa nascida na colônia, apresentando crescimento tanto do número de crianças quanto do de escravos em idade produtiva. Tais dados parecem corroborar a idéia de Douglas Libby, quando este defende que a virada do século XVIII para o XIX teria sido um momento de maior importância do crescimento natural da população mancípia de Minas Gerais.

A noção de africano, porém, não aparece nos documentos. Essa é apenas uma caracterização do pesquisador, para indicar os procedentes do tráfico atlântico. Nas palavras de Sheila de Castro Faria,

Homens e mulheres nascidos na África assumiam designações variadas ou por elas eram identificados, no Brasil. Algumas vezes era o porto de embarque; outras, mais genéricas e criadas no Brasil; ainda outras, raramente, de seus próprios grupos étnicos, mas certamente nunca era a de africano(a) ${ }^{11}$

Nesse sentido, talvez sejam necessárias algumas palavras sobre a forma pela qual estaremos entendendo as designações do tráfico, como expressão de uma identidade étnica. Muito se tem discutido, entre os historiadores, a questão da organização dos chamados grupos étnicos. Desde a década de 1960, em grande medida em função do processo de descolonização, as ciên-

${ }^{11}$ Sheila de Castro Faria, Sinhás Pretas, Damas Mercadoras: as pretas minas nas cidades do Rio de Janeiro e São João del Rei (1700 - 1850), Tese de Titular, Niterói, UFF, 2004, p. 133. 
cias sociais intensificaram os debates em torno das questões étnicas. Fredrik Barth, Abner Cohen e muitos dos seus seguidores foram responsáveis por uma revisão profunda do conceito de etnicidade. Abandonou-se a concepção de que era possível o encontro de unidades étnicas no seu sentido original, passando-se a se preocupar com a identificação da diversidade do grupo em sua organização e não como os traços culturais eram distribuídos. Deste modo, o grupo étnico passou a ser visto não como uma unidade natural/pura, mas sim como uma unidade que, dotada de uma cultura, empreende um processo de reconstrução de suas formas de organização em meio às condições políticas, culturais e econômicas impostas pela situação vivida. ${ }^{12}$

A diáspora promovida pelo tráfico atlântico de cativos colocou para a historiografia brasileira questões muito semelhantes quanto ao processo de formação e definição dos grupos étnicos. Como analisou Mary Karasch, as nações africanas que chegaram ao Brasil, na maioria das vezes, ostentaram nomes classificatórios impostos pelo tráfico, os quais se referiam, na quase totalidade, aos portos de embarque dos cativos. Essas nações não correspondiam, efetivamente, aos grupamentos originais daqueles homens. ${ }^{13}$

João Reis, no entanto, talvez tenha sido um dos primeiros a mostrar como estas denominações do tráfico foram reapropriadas pelos escravos e ex-escravos de forma a constituírem unidades étnicas formadas em meio aos embates políticos e culturais vigentes na sociedade escravista brasileira. ${ }^{14}$ Mariza Soares preferiu compreender os nomes classificatórios do tráfico enquanto grupos de procedência, admitindo também que estes poderiam recriar, no ambiente da escravidão, relações múltiplas de solidariedade, tendo nas irmandades um dos espaços privilegiados de manifestação. ${ }^{15}$

Nos registros paroquiais e na documentação das irmandades, na maioria dos casos, o que é possível identificar são as nações definidas pelo tráfico. Os escrivãos responsáveis pelos assentos, quando faziam menção à origem

${ }^{12}$ Philippe Poutignat e Jocelyne Streiff-Fenart, Teorias da Etnicidade, São Paulo, UNESP, 1998, p. 61-64; Manuela Carneiro da Cunha, Antropologia do Brasil: mito, história e etnicidade, São Paulo, Brasiliense/EDUSP, 1986, p. 94.

${ }^{13}$ Mary C. Karasch, A vida dos escravos no Rio de Janeiro 1808-1850, São Paulo, Cia. das Letras, 2000, p .35-66.

${ }^{14}$ João José Reis, Rebelião escrava no Brasil: a história do levante dos malês (1835), 2. ed, São Paulo, Brasiliense, 1987; "Identidade e diversidade étnicas nas irmandades negras no tempo da escravidão", Tempo - Revista do Departamento de História da UFF, Rio de Janeiro, Relume Dumará, v. 2, n. 3, 1997.

${ }^{15}$ Mariza de Carvalho Soares, Devotos da Cor: identidade étnica, religiosidade e escravidão no Rio de Janeiro, século XVIII, Rio de Janeiro, Civilização Brasileira, 2000, p. 109-119. 
dos cativos e libertos procedentes da África, utilizavam freqüentemente as denominações "mina", "angola”, "congo", "benguela", entre outras. Pode-se observar, a exemplo do que argumenta João Reis, que as denominações do tráfico efetivamente foram reapropriadas e utilizadas pelos negros de forma a se organizarem política e culturalmente. Deste modo, pensamos poder compreender as nações do tráfico enquanto grupos étnicos organizacionais, a exemplo do que faz Manuela Cunha com base na leitura de Abner Cohen. ${ }^{16}$

Diante desta questão, na Tabela 5 , podemos observar as nações africanas presentes nos registros de óbito de São João del Rei.

\section{Tabela 5 - Procedência dos Escravos Africanos por décadas}

\begin{tabular}{|c|c|c|c|c|c|c|c|c|c|c|}
\hline Período & \multicolumn{2}{|c|}{$1782-1790$} & \multicolumn{2}{|c|}{$1791-1800$} & \multicolumn{2}{|c|}{$1801-1810$} & \multicolumn{2}{|c|}{ 1811-1820\# } & \multicolumn{2}{|c|}{$1821-1822$} \\
\hline Angola & 291 & $48,7 \%$ & 368 & $36,2 \%$ & 220 & $30,2 \%$ & 41 & $25,8 \%$ & 10 & $31,2 \%$ \\
\hline Benguela & 79 & $13,2 \%$ & 307 & $30,2 \%$ & 279 & $38,3 \%$ & 64 & $40,3 \%$ & 6 & $18,7 \%$ \\
\hline $\begin{array}{l}\text { Benguela de Nação } \\
\text { Guiné Bissau }\end{array}$ & 1 & $0,2 \%$ & \multicolumn{2}{|c|}{ - } & \multicolumn{2}{|c|}{-} & \multicolumn{2}{|c|}{-} & \multicolumn{2}{|c|}{ - } \\
\hline Cabinda & 10 & $1,6 \%$ & 28 & $2,7 \%$ & 18 & $2,5 \%$ & 10 & $6,3 \%$ & 3 & $9,4 \%$ \\
\hline Cabo Verde & 6 & $1,0 \%$ & \multicolumn{2}{|c|}{ - } & 2 & $0,3 \%$ & \multicolumn{2}{|c|}{ - } & \multicolumn{2}{|c|}{ - } \\
\hline Cobú & 13 & $2,2 \%$ & 4 & $0,4 \%$ & - & & & & . & \\
\hline Cassange & 1 & $0,2 \%$ & 4 & $0,4 \%$ & 9 & $1,2 \%$ & 2 & 1,2 & 1 & $3,1 \%$ \\
\hline Camundongo & \multicolumn{2}{|c|}{-} & \multicolumn{2}{|c|}{-} & 1 & $0,1 \%$ & \multicolumn{2}{|c|}{ - } & \multicolumn{2}{|c|}{ - } \\
\hline $\begin{array}{l}\text { Camundongo ou } \\
\text { Angola }\end{array}$ & 1 & $0,2 \%$ & \multicolumn{2}{|c|}{-} & \multicolumn{2}{|c|}{-} & \multicolumn{2}{|c|}{ - } & \multicolumn{2}{|c|}{-} \\
\hline Congo & 40 & $6,7 \%$ & 94 & $9,2 \%$ & 56 & $7,7 \%$ & 13 & 8,1 & 4 & $12,5 \%$ \\
\hline Courano & 5 & $0,8 \%$ & 1 & $0,1 \%$ & \multicolumn{2}{|c|}{-} & \multicolumn{2}{|c|}{ - } & \multicolumn{2}{|c|}{-} \\
\hline Ganguela & 2 & $0,3 \%$ & 3 & $0,3 \%$ & 14 & $1,9 \%$ & \multicolumn{2}{|c|}{ - } & 1 & $3,1 \%$ \\
\hline Mina & 118 & $19,7 \%$ & 109 & $10,7 \%$ & 59 & $8,1 \%$ & 7 & $4,4 \%$ & 2 & $6,3 \%$ \\
\hline Moçambique & 1 & $0,2 \%$ & 2 & $0,2 \%$ & \multicolumn{2}{|c|}{ - } & \multicolumn{2}{|c|}{ - } & \multicolumn{2}{|c|}{-} \\
\hline Mofumbe & 2 & $0,3 \%$ & 18 & $1,8 \%$ & 18 & $2,5 \%$ & 9 & $5,7 \%$ & 2 & $6,3 \%$ \\
\hline Monjolo & 13 & $2,2 \%$ & 32 & $3,2 \%$ & 9 & $1,2 \%$ & 3 & $1,9 \%$ & & - \\
\hline Nagô & 5 & $0,8 \%$ & 6 & $0,6 \%$ & 1 & $0,1 \%$ & \multicolumn{2}{|c|}{ - } & \multicolumn{2}{|c|}{ - } \\
\hline Rebolo & 9 & $1,5 \%$ & 39 & $3,8 \%$ & 43 & $5,9 \%$ & 9 & $5,7 \%$ & 3 & $9,4 \%$ \\
\hline Xamba & 1 & $0,2 \%$ & \multicolumn{2}{|c|}{ - } & \multicolumn{2}{|c|}{-} & \multicolumn{2}{|c|}{-} & & - \\
\hline Tapa & & - & 1 & $0,1 \%$ & & - & & - & & - \\
\hline Ilegível & & - & 1 & $0,1 \%$ & & - & 1 & $0,6 \%$ & & - \\
\hline Total & 598 & $100,0 \%$ & 1.017 & $100,0 \%$ & 729 & $100,0 \%$ & 159 & $100,0 \%$ & 32 & $100,0 \%$ \\
\hline
\end{tabular}

Fonte: APNP. Registros Paroquiais de Óbitos - Matriz de Nossa Senhora do Pilar de São João del Rei - 1782-1807. \# Não existem registros para os anos 1815,1816 e 1817.

\footnotetext{
${ }^{16}$ Manuela Carneiro da Cunha, op. cit., p. 94.
} 
Nota-se de imediato o amplo predomínio de angolas e benguelas, seguidos dos minas. Já é usual, na historiografia sobre escravidão em Minas Gerais, a afirmação de que, num primeiro momento dos setecentos, predominaram os cativos de origem mina, desembarcados, sobretudo, na Bahia e remetidos para as terras mineiras. Segundo Mariza Soares,

Ao iniciar o século XVIII já existem duas rotas de escravos em direção às lavras de ouro: a primeira sai da cidade de Salvador e, passando pela Vila de Cachoeira, segue por terra pelo Caminho do Sertão até as Minas; a outra sai de Salvador por mar, passa pelo Rio de Janeiro onde se junta à rota que vem da Mina para o Rio de Janeiro, segue por mar até Parati e daí sobe por terra a Serra da Mantiqueira até chegar às Minas. De acordo com o livro de passaportes e guias da cidade de Salvador entre os anos de 1718 e 1729, saem dessa cidade 21.238 escravos sendo que 19.500 deles com destino a Minas. ${ }^{17}$

A partir de meados do século XVIII, teriam predominado os escravos procedentes da África banto, ingressados a partir do porto do Rio de Janeiro. Segundo Luna e Costa,

(...) novos estudos vieram demonstrar a elevada participação do grupo sudanês em áreas meridionais, inclusive em Minas Gerais. Paralelamente, firma-se o consenso de terem os sudaneses sido trazidos às Gerais em razão de possuírem conhecimento técnico relativamente avançado quando comparado ao dos bantos e estarem familiarizados com o trabalho extrativo mineral em suas "nações" de origem.

(...)

À época do auge da faina aurífera parece ter havido preponderância do grupo sudanês; reciprocamente, ao tempo de decadência, passaram a dominar os bantos. Revelou-se, paralelamente, a tendência a "substituir" aqueles por estes, fato a comprovar o estreito liame entre o elemento sudanês e o trabalho exploratório. $^{18}$

Infelizmente, nossos dados iniciam-se apenas em 1782. Eles corroboram o predomínio dos bantos, mas destacam também a continuidade da importância dos minas, ainda que em patamares cada vez menos expressivos. Assim, entre 1782 e 1790 , os minas representavam quase $20 \%$ dos cativos africanos e, entre 1811 e 1820 , passam a corresponder a menos de $5 \%$ deste universo.

${ }^{17}$ Mariza Soares, "Histórias Cruzadas: os mahi setecentistas no Brasil e no Daomé", in: Manolo Florentino (org.), Tráfico, Gativeiro e Liberdade - Rio de Janeiro, séculos XVII-XIX, Rio de Janeiro, Civilização Brasileira, 2005, p. 159-160.

${ }^{18}$ Francisco Vidal Luna e Iraci del Nero da Costa, Minas Colonial: Economia e Sociedade, São Paulo, Livraria Pioneira Editora / FIPE, 1982, p. 48-50. 
Constata-se também um decréscimo na proporção dos angolas e um significativo aumento dos benguelas, a partir do período entre 1791 e 1800 . À exceção dos últimos dois anos estudados, os angolas são superados proporcionalmente pelos benguelas, a partir de 1800, o que corresponde a mudanças ocorridas no tráfico em território africano. ${ }^{19}$

É interessante notar que os benguelas parecem ter constituído um grupo coeso em torno de uma identidade comum. A partir da década de 1780, eles se tornaram o grupo de procedência que proporcionalmente mais realizou casamentos endogâmicos, em São João del Rei. ${ }^{20}$ Afonso Graça Filho - trabalhando com a vizinha freguesia de São José del Rei e tendo como fonte inventários post-mortem - também observou que, dentre os casamentos endogâmicos, a maioria unia um casal formado por benguelas. ${ }^{21}$ Além disso, localizamos, na documentação sobre a Irmandade de Nossa Senhora do Rosário de São João del Rei, um livro com certidões de missas de irmãos da "Nobre Nação Benguela”, indício de que eles formavam um grupo com identidade própria e uma certa autonomia dentro da irmandade.

\section{A Nobre Nação Benguela}

Aos dois de novembro de 1803 foi aberto, na Vila de São João del Rei, um livro de certidões que se destinava a serem lançadas as missas da Nobre Nação Benguela. Este interessante e valioso documento traz à tona a existência de uma congregação de caráter étnico instituída por escravos e forros procedentes da região de Benguela, na África Centro-Ocidental. Embora datado de 1803, as anotações ao longo do livro permitem que se perceba que a congregação havia sido criada, pelo menos, desde a última década do século XVIII, já que se encontra um recibo de 1793, passado pelo Padre Luís Pereira Gonzaga, dando conta de duas missas rezadas pelas almas de Ana e Mariana Lopes, mandadas dizer por João Ladino. Talvez este mesmo João Ladino tenha sido alvo da caridade dos seus "parentes" que, em 1799, mandaram dizer por sua

\footnotetext{
${ }^{19}$ Joseph C. Miller, "A economia política do tráfico angolano de escravos no século XVIII", in: Selma Pantoja e José Flávio Sombra Saraiva, Angola e Brasil nas Rotas do Atlântico Sul, Rio de Janeiro, Bertrand do Brasil, 1999.

${ }^{20}$ Denílson de Cássio Silva, "Casamento de Escravos (São João del Rei, século XVIII e primeira metade do XIX)". Trabalho apresentado no 2. Simpósio Escravidão e Mestiçagem - Histórias Comparadas, realizado na UFMG, em 06 e 07 de março de 2006.

${ }^{21}$ Afonso d’Alencastro Graça Filho, "Famílias Escravas em São José do Rio das Mortes, 17431850”. Trabalho apresentado no 2․ Simpósio Escravidão e Mestiçagem - Histórias Comparadas, realizado na UFMG, em 06 e 07 de março de 2006.
} 
alma 24 missas. ${ }^{22}$ Apesar de não haver uma regularidade na apresentação das certidões, parece ser possível afirmar que a congregação funcionou em boa parte do século XIX, já que consta do livro uma certidão dando conta de missa celebrada pela alma de João da Cunha Preto, em 1871.

Além dos recibos de missas, que compõem a maior parte das anotações do livro, recibos outros e certidões também são assentados, permitindo que se chegue a outras importantes informações. Um desses recibos dava conta de três oitavas de ouro, dadas pela Nação Benguela, para a Irmandade do Rosário dos Pretos, de forma a resolver uma demanda com o Vigário. Dá-se ainda conta que as outras nações também contribuíram para a "nossa Irmandade", sendo o recibo assinado pelo Rei de Congo João Martins Coelho. ${ }^{23}$ É possível perceber que, além dos benguelas, outros grupos estavam organizados no interior da Irmandade. Ao longo do documento vai ficando clara a institucionalização da congregação Benguela, sendo mencionada a existência dos cargos de Rei, Tesoureiro, Procurador, Duques e Marqueses da "Nobre Nação".

A "Nação Benguela" contava ainda com um cofre onde eram depositadas as esmolas retiradas para o sustento da congregação. Parte destas esmolas advinha dos "Folguedos da Praia". A praia localizava-se às margens do Córrego do Lenheiro ou do Tejuco que cortava a Vila de São João, portanto, um lugar central e de grande visibilidade. Data de 1719 a construção da primeira ponte de madeira sobre esse córrego, motivando a expansão da Vila para o lado oposto, onde seriam erguidos importantes edifícios como a Intendência e as casas de Fundição. ${ }^{24}$ Nos registros da Irmandade do Rosário constam que outros grupos de africanos, como os ganguelas, também recolhiam esmolas na localidade. Em 1791, três escravos - João Barbosa, Francisco e João Cardoso - foram admitidos gratuitamente em compensação às "esmolas retiradas pelas gentes ganguelas na praia". ${ }^{25}$

As esmolas permitiram que, em 1803, em nome da congregação, os forros João Machado Alves Pontes e João Tomás Ferreira comprassem uma casa que foi denominada de "Palácio Real de toda a Nação de Benguela". O termo,

${ }^{22}$ APNP (Arquivo da Paróquia de Nossa Senhora do Pilar de São João del Rei), Certidões de Missas da Nobre Nação Benguela,1803.

${ }^{23}$ Ibidem.

${ }^{24}$ Geraldo Guimarães, São João Del Rei - século XVIII: história sumária, São João del Rei, Edição do Autor, 1996, p. 39.

${ }^{25}$ Arquivo da Igreja de Nossa Senhora do Rosário de São João del Rei, Entrada de Irmãos, Livro 17. 
assentado no livro, dizia que as esmolas que permitiram aquela aquisição eram frutos da contribuição dos forros e cativos daquela nação e que, portanto, a casa era da nação, não podendo os irmãos compradores dispor da mesma sem o assentimento do grupo. ${ }^{26}$

Os benguelas de São João del Rei reforçam o que vem sendo afirmado pela historiografia brasileira quanto às irmandades terem sido espaços privilegiados para a afirmação de identidades coletivas, principalmente, para africanos e seus descendentes. No caso de Minas Gerais, especificamente com relação aos africanos, embora não se encontre, como no Rio de Janeiro e na Bahia, uma maior pulverização na construção de templos distintos dos diversos grupos étnicos, esta diferenciação estava presente em torno das devoções e de congregações como estas que ora estamos analisando. ${ }^{27}$ Por outro lado, a estrutura da "Nobre Nação Benguela" é muito semelhante àquela da congregação Mahi, estudada por Mariza Soares, existente na Irmandade de Santo Elesbão e Santa Efigênia, no Rio de Janeiro. ${ }^{28}$

Em artigo recente, a autora reafirmou a importância da criação dessas congregações no interior das irmandades como um fator de resolução de conflitos entre os grupamentos étnicos. Soares também enfatiza o papel desses grupos no tocante à reversão das condições da escravidão a favor de seus membros. Tais associações cumpririam o papel de reler as estruturas hierárquicas do Antigo Regime, pois, com a constituição das folias que elegiam reis, rainhas e suas cortes, estes grupos estariam se reapropriando de parâmetros de poder vigentes na sociedade colonial para recriarem verdadeiras linhagens religiosas com base num passado africano de glórias que se reproduziria nas suas procissões, festas, entre outras manifestações. ${ }^{29}$ No que tange, especificamente, à coroação de reis negros, Marina de Mello e Souza já havia assinalado como este fator significou um processo de recriação de tradições onde se mesclaram fragmentos de uma memória africana e elementos da cultura católica européia. A força simbólica que reis e chefes tribais possuíam nas sociedades africanas fez com que os africanos da diáspora buscassem se reunir em torno destas

\footnotetext{
${ }^{26}$ APNP, Certidões de Missas da Nobre Nação Benguela,1803.

${ }^{27}$ Sobre a comparação entre as irmandades negras no Rio de Janeiro e em Mina Gerais, no século XVIII, cf. Anderson José M. de Oliveira, Os Santos Pretos Carmelitas: culto dos santos, catequese e devoção negra no Brasil Colonial, Tese de Doutorado, Niterói, UFF, 2002, p. 377406.

${ }^{28}$ Mariza de Carvalho Soares, Devotos da Cor..., op.cit.

${ }^{29}$ Mariza Soares, "Histórias cruzadas: os mahi setecentistas no Brasil e no Daomé", op. cit., p. $134-135 ; 151-153$.
} 
lideranças, de forma a criar um ambiente que resgatasse minimamente elementos das suas culturas locais. ${ }^{30}$ Deste modo, tal processo ensejou a construção de inúmeras identidades étnicas representativas dos diversos povos africanos inseridos na diáspora africana nas Américas.

\section{Diáspora africana e identidades étnicas: os benguelas de São João del Rei}

\subsection{Os benguelas em São João del Rei}

A organização da "Nobre Nação Benguela" parece confirmar a tendência de análises historiográficas mais recentes, no que tange à organização dos grupos étnicos e suas relações com as irmandades religiosas, além de colocar outros problemas para reflexão. Lançando inicialmente o olhar para a presença dos benguelas dentro da Irmandade do Rosário, onde a "Nação" é estruturada, tem-se o seguinte quadro, elaborado a partir do livro de entrada de irmãos:

Tabela 6 - Grupos Étnicos na Irmandade de Nossa Senhora do Rosário dos Pretos de São João del Rei (1750-1848)

\begin{tabular}{|l|c|c|}
\multicolumn{1}{c|}{$\quad$ Procedência } & N. & $\%$ \\
\hline América Portuguesa (Crioulos) & 230 & 27,9 \\
\hline Benguela & 149 & 18,1 \\
\hline Angola & 128 & 15,5 \\
\hline Mina & 90 & 10,9 \\
\hline Congo & 53 & 6,4 \\
\hline Rebolo & 35 & 4,2 \\
\hline Ganguela & 28 & 3,4 \\
\hline Cabunda & 21 & 2,5 \\
\hline Nagô & 18 & 2,2 \\
\hline Mocumbe & 13 & 1,6 \\
\hline Songa & 12 & 1,5 \\
\hline Monjolo & 10 & 1,2 \\
\hline Moçambique & 8 & 1,0 \\
\hline Cassange & 8 & 1,0 \\
\hline Camundongo & 4 & 0,5 \\
\hline Cobu & 3 & 0,4 \\
\hline Da Costa & 3 & 0,4 \\
\hline Cabo Verde & 2 & 0,2 \\
\hline
\end{tabular}

${ }^{30}$ Marina de Mello e Souza, Reis Negros no Brasil Escravista: história da festa de coroação de Rei Congo, Belo Horizonte, UFMG, 2002, p. 47, 207-208. 


\begin{tabular}{|c|c|c|}
\hline Procedência & N. & $\%$ \\
\hline Não identificado & 2 & 0,2 \\
\hline Bambila & 1 & 0,1 \\
\hline Bamboira & 1 & 0,1 \\
\hline Carabari & 1 & 0,1 \\
\hline Daomé & 1 & 0,1 \\
\hline De Nação & 1 & 0,1 \\
\hline Guicama & 1 & 0,1 \\
\hline Muhimbe & 1 & 0,1 \\
\hline Totais & 824 & 100,0 \\
\hline
\end{tabular}

A presença majoritária dos benguelas entre os africanos da Irmandade está diretamente relacionada ao ritmo do tráfico atlântico, que promoveu um maior embarque de cativos no porto de Benguela no século XVIII, principalmente na sua segunda metade. A concorrência de outras potências estrangeiras no porto de Luanda e as disputas entre comerciantes reinóis, de um lado, e negociantes angolanos e brasileiros contribuíram para tornar mais tensas as relações na região. Além disso, os governadores de Angola vinham constantemente interferindo no comércio de cativos, aproveitando-se de sua posição para auferir vantagens sobre o mesmo, inclusive violando regras na concessão de licenças para o abastecimento de navios no porto de Luanda, o que vinha prejudicando o interesse dos mercadores atuantes na região. O conjunto desses problemas acabou por deslocar os apresamentos de cativos para o planalto de Bihé, terra dos Ovimbundu, e o tráfico para a cidade de São Filipe de Benguela, fundada no século XVII. O porto em questão, em função das fortes correntes que vinham do norte, era de difícil acesso pelo mar para as autoridades metropolitanas de Luanda e de mais fácil acesso para as embarcações que vinham principalmente do Rio de Janeiro. ${ }^{31}$ Embora o tráfico por Luanda tenha mantido fundamental importância, Benguela surgiu como uma importante alternativa a consolidar-se na segunda metade dos setecentos. É justamente neste período que se pode observar a entrada dos oriundos desta região na Irmandade do Rosário. O primeiro registro encontrado é de 1761, ocorrendo a partir de então uma intensificação das filiações, principalmente da década de 1790 até 1843 , quando se registra $79,2 \%$ dos assentos do grupo.

\footnotetext{
${ }^{31}$ Manolo Florentino, Em Costas Negras: uma história do tráfico de escravos entre a África e o Rio de Janeiro (séculos XVIII e XIX), São Paulo, Cia. das Letras, 1997, p. 99; Joseph C. Miller, op. cit., p. 11-35; Roquinaldo Ferreira, Transforming Atlantic Slaving: Trade,Warfare and Territorial Control in Angola, 1650-1800, Tese de Doutorado, Los Angeles, University of California, 2003, p. 24-35.
} 
O aumento do número de benguelas na Irmandade era, na verdade, o reflexo do crescimento do grupo em Minas Gerais; os dados de Laird Bergad apontam para o predomínio destes e dos angolas enquanto origem dos escravos da capitania, a partir de $1750 .{ }^{32}$ Especificamente para São João del Rei, a Tabela 5 comprova um crescimento significativo dos benguelas entre a população cativa e a Tabela 7 demonstra o mesmo entre os libertos e "livres"33 africanos:

\section{Tabela 7 - Procedência de Africanos Forros e "Livres" por década}

\begin{tabular}{|c|c|c|c|c|c|c|c|c|c|c|c|c|}
\hline \multirow{2}{*}{$\begin{array}{l}\text { Período } \\
\text { Procedência }\end{array}$} & \multicolumn{3}{|c|}{$1782-1790$} & \multicolumn{3}{|c|}{$1791-1800$} & \multicolumn{2}{|c|}{$1801-1810$} & \multicolumn{2}{|c|}{ 1811-1820\# } & \multicolumn{2}{|c|}{$1821-1822$} \\
\hline & & Forro & "Livre" & & Forro & "Livre" & Forro & "Livre" & Forro & "Livre" & Forro & "Livre" \\
\hline Angola & & $7,9 \%$ & $8 \quad 50,0 \%$ & 14 & $24,1 \%$ & $18 \quad 17,2 \%$ & $17 \quad 38,6 \%$ & $31 \quad 34,0 \%$ & $5 \quad 21,8 \%$ & $2 \quad 25,0 \%$ & $360,0 \%$ & \\
\hline Benguela & & & $1 \quad 6,3 \%$ & 10 & $17,2 \%$ & $12 \quad 11,5 \%$ & $12 \quad 27,3 \%$ & $1920,8 \%$ & $8 \quad 34,8 \%$ & $3 \quad 37,5 \%$ & $120,0 \%$ & \\
\hline Cabinda & & & & & & $1 \quad 10,9 \%$ & & $1 \quad 1,1 \%$ & $1 \quad 4,3 \%$ & $112,5 \%$ & & \\
\hline Cabo Verde & 2 & $5,1 \%$ & & 2 & $3,5 \%$ & $3 \quad 2,9 \%$ & $1 \quad 2,3 \%$ & & & & & \\
\hline Cobú & 1 & $2,6 \%$ & $1 \quad 6,3 \%$ & 1 & $1,7 \%$ & & $2 \quad 4,5 \%$ & & & & & \\
\hline Cassange & & & & & & $2 \quad 1,9 \%$ & & $2 \quad 2,2 \%$ & & & & \\
\hline Congo & 2 & $5,1 \%$ & & 4 & $6,9 \%$ & $9 \quad 8,6 \%$ & $12,3 \%$ & $5 \quad 5,5 \%$ & $3 \quad 13,1 \%$ & & & \\
\hline Courano & & & $1 \quad 6,3 \%$ & & & $1 \quad 0,9 \%$ & & & & & & \\
\hline Mina & 8 & $20,5 \%$ & $5 \quad 31,1 \%$ & 22 & $37,9 \%$ & $51 \quad 48,6 \%$ & $10 \quad 22,7 \%$ & $28 \quad 30,9 \%$ & $4 \quad 17,4 \%$ & $225,0 \%$ & & \\
\hline Mofumbe & & & & & & $1 \quad 0,9 \%$ & & $1 \quad 1,1 \%$ & & & & \\
\hline Monjolo & & & & 2 & $3,5 \%$ & $2 \quad 1,9 \%$ & $1 \quad 2,3 \%$ & & & & & \\
\hline Nagô & & & & & & $1 \quad 0,9 \%$ & & & & & & \\
\hline Rebolo & & & & 3 & $5,2 \%$ & $4 \quad 3,8 \%$ & & $4 \quad 4,4 \%$ & $1 \quad 4,3 \%$ & & $120,0 \%$ & $1100 \%$ \\
\hline Ilegível & 19 & $48,7 \%$ & & & & & & & $1 \quad 4,3 \%$ & & & \\
\hline Total & 39 & $100,0 \%$ & $16100,0 \%$ & & $100,0 \%$ & $105100,0 \%$ & $44100,0 \%$ & $91100,0 \%$ & $23100,0 \%$ & $8100,0 \%$ & $5100,0 \%$ & $1100,0 \%$ \\
\hline
\end{tabular}

Fonte: APNP. Registros Paroquiais de Óbitos - Matriz de Nossa Senhora do Pilar de São João del Rei - 1782-1807.

\# Não existem registros para os anos 1815,1816 e 1817.

Todavia, se numericamente os benguelas destacavam-se no conjunto da população e em filiação à Irmandade, tal fato não parece ter se traduzido em representatividade de poder dentro do Rosário de São João del Rei. Ao tomar-se a verificação dos cargos ocupados como índice para aferir este fator, encontra-se a seguinte situação:

\footnotetext{
${ }^{32}$ Laird W. Bergad, op. cit., p. 228-229.

${ }^{33}$ Estamos mantendo a designação de "livres" para aqueles que foram identificados como africanos, por suas nações de procedência, mas não foram explicitados nos registros como forros, embora nitidamente se tratasse de ex-escravos.
} 


\section{Tabela 8 - Distribuição dos Cargos pelos Grupos dentro da Irmandade de Nossa Senhora do Rosário dos Homens Pretos de São João Del Rei (1750-1848)}

\begin{tabular}{l|c|c|}
\hline Procedência & N. de Cargós Ocupados & $\%$ \\
\hline América Portuguesa (Crioulos) & 48 & 37,2 \\
\hline Angolas & 25 & 19,4 \\
\hline Minas & 24 & 18,6 \\
\hline Congos & 10 & 7,7 \\
\hline Benguelas & 5 & 3,9 \\
\hline Rebolos & 4 & 3,1 \\
\hline Nagôs & 3 & 2,3 \\
\hline Moçambiques & 2 & 1,5 \\
\hline Monjolos & 2 & 1,5 \\
\hline Da Costa & 2 & 1,5 \\
\hline Ganguelas & 1 & 0,8 \\
\hline Mofumbes & 1 & 0,8 \\
\hline Cabundas & 1 & 0,8 \\
\hline Camundongos & 1 & 0,8 \\
\hline Totais & 129 & 100,0 \\
\hline Fonte: Arquivo da Igreja de Nossa Senhora do Rosário de São João del Rei - Entrada de Irmãos, Livros 17 e 20. & \\
\hline Dos 824 assentos que indicavam a origem dos irmãos, 129 fizeram menção à ocupação de cargos por estes. & \\
\hline
\end{tabular}

A ocupação de cargos nas irmandades, embora fosse por eleição, não assumia a feição de participação por sufrágio universal. Os componentes da Mesa Administrativa eram indicados por grupos de pressão que se constituíam no interior das associações. Os juizados de santos dependiam da disponibilidade de recursos dos irmãos, que deveriam contribuir com esmolas para a festa do santo em questão. Desta forma, os grupos dominantes ou mais organizados tinham condições de controlar o maior número de cargos. Da mesma forma, esta capacidade de controle e indicação dependia também da construção de alianças com outros grupos. ${ }^{34}$

Adotando um parâmetro de comparação, pode-se destacar o caso dos minas que, embora numericamente inferiores aos benguelas entre os irmãos, ocuparam um percentual bem maior de cargos. A entrada dos minas em Minas Gerais era mais antiga. Provavelmente estiveram entre os fundadores da Irmandade, criada em 1708. Entre os 24 minas que ocuparam cargos, encontram-se 21 mulheres, o que corrobora a tese de Sheila Faria, no que diz

${ }^{34}$ Mariza de Carvalho Soares, Devotos da cor..., op. cit., p. 180-189; Anderson José M. de Oliveira, op. cit., p. 337-406. 
respeito à capacidade deste grupo de amealhar pecúlio através das atividades mercantis, o que remontaria a uma atividade comum entre as mulheres na África Ocidental..$^{35}$ Deste modo, no interior da Irmandade, o grupo, apesar de numericamente inferior aos benguelas, demonstrava ter mais poder de pressão e recursos para ascender a cargos que traduziam prestígio.

Os benguelas, como um grupo mais recente na região e na Irmandade, teriam maiores dificuldades de exercer pressão e de angariar recursos, o que talvez seja uma das explicações para a necessidade de constituir uma congregação que pudesse servir como um mecanismo a reforçar a sua identidade e permitir a ocupação de cargos de prestígio que não conseguiam ocupar na direção da Irmandade.

Essa hipótese se reforça quando lembramos da tendência à maior endogamia conjugal observada entre os benguelas, tanto em São João del Rei quanto em São José del Rei, no período. ${ }^{36}$

Pode-se ilustrar o que acima foi dito através dos testamentos de Francisco Coelho de Souza e Joana de Freitas, casados, ambos forros e de Nação Benguela. O testamento de Joana foi escrito em 1821, momentos antes do seu falecimento, e o de Francisco em 1828. O testamento de Francisco é mais detalhado e é nele que descobrimos a procedência de ambos, já que Joana somente menciona que ela e o marido eram pretos forros. Após a morte de Joana, Francisco contrai novas núpcias com Luzia Marques Pinto, esta uma forra de Nação Rebolo. Tanto Francisco quanto Joana eram irmãos do Rosário e foram sepultados na capela da Irmandade. Francisco também é mencionado no livro de missas da Nobre Nação Benguela, tendo mandado, em 1805, dizer uma missa na intenção da alma de Manoel da Silva Guimarães. ${ }^{37}$

A história do casal confirma que, pelos menos nas primeiras núpcias, os benguelas mantinham-se endogâmicos, o que pode reforçar a idéia de um grupo ainda recente que necessitava consolidar-se firmando alianças entre si. Por outro lado, se corrobora a idéia do espaço da Irmandade e da Nobre Nação como lugares privilegiados de reconstrução da identidade do grupo. O livro de missas não menciona a origem do irmão que recebe a missa encomendada por Francisco, mas é bastante provável que fosse também um benguela, já

\footnotetext{
${ }^{35}$ Sheila de Castro Faria, op. cit., p. 232-240.

${ }^{36}$ Afonso d’Alencastro Graça Filho, op. cit.; Denílson de Cássio Silva, op. cit.

${ }^{37}$ AMRSJ (Arquivo do Museu Regional do São João del Rei), Testamento de Francisco Coelho de Souza, 1828; APNP, Registros Paroquiais de Óbitos (1818-1824), Testamento de Joana de Freitas, 1821; APNP, Certidões de Missas da Nobre Nação Benguela, 1803.
} 
que o grupo parecia estar ciente da necessidade do estabelecimento de laços de reciprocidade.

Um outro exemplo pode vir da história da preta forra Teresa Joaquina de Souza. Em seu testamento, escrito em 1816, declara-se oriunda da "Costa Nação Benguela”, tendo sido casada com o falecido João Henrique de Souza, dito como "preto da costa", do qual teve dois filhos que também já haviam falecido. Teresa era irmã do Rosário e, por não ter herdeiros necessários, nomeia por herdeiro universal o preto forro Caetano José de Siqueira e, na ausência dele, sua mulher Joana. Na falta de ambos, os herdeiros de Teresa seriam os crioulos Cândido e Umbelina, os dois filhos naturais da preta forra Francisca Benguela. ${ }^{38}$

Embora a origem do marido de Teresa seja mencionada de forma genérica, é bastante provável que também fosse um benguela, já que o termo "da costa" é utilizado por ela junto ao termo benguela para se auto-identificar. Por outro lado, este fora o único casamento mencionado por Teresa, parecendo ter sido o primeiro; e dentro dos padrões vistos para a região a endogamia tinha um forte peso, pelo menos nas primeiras núpcias, como fora o caso de Francisco Coelho. Por outro lado, o primeiro herdeiro de Teresa era um preto forro que em função de Teresa não ter parentes vivos os substituiu. Não seria absurdo supor que Caetano pudesse ser um benguela, o que pode ser reforçado pelo fato de que os outros herdeiros, na ausência dele e de sua mulher, eram filhos de uma mulher benguela.

Parece-nos que tais casos reforçam a hipótese de que, novos na região, os benguelas procuraram construir redes de solidariedade com base na sua identidade de procedência. Tais redes, em nossa avaliação, tiveram na "Nobre Nação" um de seus elementos fundamentais, na medida em que a congregação, ao permitir a recuperação de parte da memória africana, deu ao grupo uma identidade de fortes matizes étnicos.

\subsection{A Nobre Nação Benguela e seus significados}

A criação da "Nobre Nação Benguela" colocar-se-ia neste contexto como um dos elementos a reforçar a construção desta identidade do grupo, consolidando-a internamente de forma a fortalecê-lo nos embates com os demais grupos de africanos e descendentes. Não por acaso, um dos principais

${ }^{38}$ APNP, Registros Paroquiais de Óbitos (1818-1824), Testamento de Teresa Joaquina de Souza, 1816. 
objetivos da congregação, expresso no Livro de Certidões de Missas, era sufragar as almas dos seus nacionais. O compromisso de $1787 \mathrm{da}$ Irmandade previa rezar dez missas pelos irmãos falecidos. ${ }^{39}$ No entanto, os benguelas partilhavam de uma preocupação ainda mais acentuada com relação aos destinos dos seus mortos, prevendo a realização de mais missas.

O sufrágio aos mortos era um dos elementos da chamada "pedagogia do bem morrer", que ganha amplo destaque no Brasil dos setecentos. Difundidos a partir da doutrina do Purgatório, do final da Idade Média, os sufrágios e esmolas em intenção das almas de parentes e amigos eram vistos como uma forma de abreviar os sofrimentos daquelas no Purgatório. Alimentava-se igualmente a esperança de que, livres das penas do Purgatório, estas almas viessem a interferir a favor dos parentes e amigos vivos. ${ }^{40}$ As irmandades reforçariam esta prática tornando tais sufrágios cada vez mais exclusivos ao grupo. ${ }^{41}$

Acreditamos que tais práticas católicas tenham exercido influência sobre os benguelas e outros grupos de africanos nas irmandades. No entanto, parece-nos que esta preocupação com o culto aos mortos traduzia uma leitura do catolicismo a partir da importância que o culto aos ancestrais tinha nas sociedades africanas e, em particular, na África Centro-Ocidental. Mariza Soares percebeu preocupação semelhante entre os mahis, no Rio de Janeiro, que estabeleceram dentro de sua congregação um culto às almas, o que denotava fortes preocupações com os ancestrais. ${ }^{42}$

As sociedades da África Centro-Ocidental tendem a se estruturar em torno de linhagens, ou seja, grupos de parentesco que traçam suas origens a partir de ancestrais comuns. Neste sentido, uma das principais modalidades de culto aos mortos é o culto dos ancestrais, que invoca os mortos do clã como uma das formas de estabelecer a paz na comunidade. ${ }^{43}$ Para o conjunto desses povos, os mortos não abandonavam o mundo dos vivos, sendo a fronteira entre os dois mundos constantemente transposta. Os mortos exigiam ser,

\footnotetext{
${ }^{39}$ APNP, Compromisso da Irmandade de Nossa Senhora do Rosário dos Pretos, São João del Rei. Comarca do Rio das Mortes, 1787.

${ }^{40}$ Claudia Rodrigues, Nas Fronteiras do Além: a seculariaação da morte no Rio de Janeiro - séculos XVIII e XIX, Rio de Janeiro, Arquivo Nacional, 2005, p. 45-46.

${ }^{41}$ Adalgisa Arantes Campos, A Terceira Devoção do Setecentos Mineiro: o culto a São Miguel e Almas, Tese de Doutorado, São Paulo, USP, 1994, p. 264.

${ }^{42}$ Mariza de Carvalho Soares, Devotos da cor.., op. cit., p. 210-214.

${ }^{43}$ Wyatt Macgaffey, Religion and Society in Central África, Chicago/Londres, The University of Chicago Press, 1986, p. 63-67.
} 
constantemente, lembrados, já que isto era a garantia da boa ventura para a sociedade. ${ }^{44}$

Na medida em que os grupos étnicos procuravam organizar-se recuperando parte desta memória das linhagens africanas, havia todo um sentido para os benguelas estarem atentos ao culto de seus mortos. Deste modo, traziam para sua congregação esta preocupação que, ao mesmo tempo, invocava para o grupo a proteção de seus ancestrais e contribuía de forma decisiva para sedimentar as solidariedades entre eles, fortalecendo ainda mais o processo de construção de uma identidade sociocultural.

Uma outra questão que nos parece reforçar o que acima foi argumentado é a aquisição da casa e sua denominação como "Palácio Real de toda a Nação de Benguela". O termo que registra a aquisição da casa é repleto de significados:

João Machado Alves Fontes e João Tomás Ferreira Guimarães pretos forros que servimos nesta Nobre Nação de Benguela.

Certifico e por termos fé em como estas casas é (sic) da Nobre Nação de Benguela declarando que os ditos compradores João Machado Alves Fontes e João Tomás Ferreira Guimarães compraram estas casas com o dinheiro das esmolas que tiramos entre os irmãos forros e cativos e do que está estabelecida por Palácio Real de toda a Nação de Benguela e por os ditos compradores serem forros é que é que estão por cabeça desta compra não porque sejam donos e possuidores como seus porque foi a custa e finta entre todos que consistem os cativos desta nobre nação e não poderão dispor nem vender as ditas casas sem a nação toda junta fazerem Mesa e Haver por bem e para clareza entre todos que achamos presente mandamos lavrar os presente termo que assinaram os da dita nação que se acham presente dado e passado em o Real Palácio. Aos 30 de Novembro de 1803 anos (...). 45

Uma primeira questão que merece ser mencionada é quanto à aquisição das casas. Não há condições de se afirmar que o uso da palavra casa no plural signifique que mais de uma foi adquirida, até porque o próprio documento fala das casas estabelecidas por palácio, este no singular. Sheila Faria mostra que a expressão casas era bastante comum, no século XVIII, para referir-se a "casas de vivenda" ou "de morada", o que expressava um conjunto onde se vivia e

${ }^{44}$ James H. Sweet, Recreating África: culture, kinship, and religion in the African-Portuguese World, 1441-1770, Chapel Hill/Londres, The University of North Carolina Press, 2003, p. 104-105.

${ }^{45}$ APNP, Certidões de Missas da Nobre Nação Benguela, 1803. 
onde se conseguia a sobrevivência. ${ }^{46}$ As observações da autora referem-se ao meio rural e não ao espaço urbano. Todavia, não nos parece que os significados na utilização do espaço da casa, na colônia, fossem profundamente diferentes. Não temos condições de precisar o uso que os benguelas fizeram de suas "casas" ou "casa". Entretanto, ao que tudo indica, ela assumia um sentido de sobrevivência simbólica para o grupo, sendo um elemento importante na definição de sua identidade. A idéia de conjunto de vivência e sobrevivência coletiva, a qual se refere Sheila Faria, pode ensejar uma série de questões que reforcem a identidade do próprio grupo.

Uma primeira questão pode ser discutida com relação ao próprio espaço da casa. Não é novidade na historiografia sobre a escravidão, principalmente no espaço urbano, a posse ou aluguel de casas por escravos e libertos, locais estes onde ocorriam encontros, por vezes, bastante suspeitos aos olhos das autoridades. Era este o caso da casa alugada pelo forro mina José Pereira, onde através de uma devassa, analisada por João Reis, se destruiu o calundu existente, em 1785, no Pasto de Cachoeira, na Bahia. Segundo João Reis, não resta dúvidas de que a casa era um centro cerimonial, não só pelos relatos dos cânticos e danças que lá eram praticados, mas também pelos objetos de culto encontrados pelos policiais. Ainda segundo o autor, pode-se perceber nos traços dos cultos praticados a predominância da religião dos vodus, demarcando a forte presença de grupos jejes oriundos da Costa da Mina. ${ }^{47} \mathrm{O}$ caráter étnico na vivência e sobrevivência no espaço parece bastante claro.

No Rio de Janeiro, nas primeiras décadas do século XIX, Leila Algranti também identifica, através da documentação policial, a existência de casas semelhantes àquela analisada por João Reis. Segundo a autora, as autoridades policiais tinham grandes preocupações com essas casas, já que poderiam dar lugar a ajuntamentos ilegais de escravos ou libertos, além do temor da população livre em relação ao poder que os feiticeiros negros exerciam sobre a população escrava. Nesse contexto, a autora menciona, em 1814, a ordem do intendente de polícia para se apreender, na casa do preto mina Valente José, ervas e raízes que foram vistas durante a sua prisão. Em 1819, seria presa uma preta forra, na Freguesia do Irajá, por ter ela "casa de calundus", onde

\footnotetext{
${ }^{46}$ Sheila de Castro Faria, A colônia em movimento: fortuna e família no cotidiano colonial, Rio de Janeiro, Nova Fronteira, 1998, p. 370.

${ }^{47}$ João José Reis, "Magia Jeje na Bahia: a invasão do calundu do Pasto de Cachoeira, 1785", Revista Brasileira de História, São Paulo, ANPUH/Marco Zero, v. 8, n. 16, 1988, p. 67-72.
} 
se sabiam praticar várias superstições com ajuntamento de muitas pessoas e escravos fugidos. ${ }^{48}$

O termo calundu associado a casas, tanto na Bahia quanto no Rio de Janeiro, também foi encontrado por Laura de Mello e Souza no vocabulário inquisitorial que o associava a cerimônias praticadas pelos negros onde estavam presentes a dança, o transe e as oferendas aos ídolos. Na mentalidade do Santo Ofício, o fenômeno constituía-se numa variante do demoníaco sabbat. ${ }^{49}$ No entanto, segundo James Sweet, o termo seria uma corruptela de quilundo, palavra de origem kimbundo que se refere à possessão dos humanos por seres espirituais, geralmente ancestrais. Segundo o autor, na África Central, tal ato de possessão estaria diretamente relacionado às atividades de cura. Considerando-se que naquela região da África os infortúnios, entre eles as doenças, eram sempre vistos como de origem espiritual, a possessão funcionaria como um meio de consulta aos ancestrais para que estes indicassem os caminhos a serem seguidos para a vitória sobre os males que afligiam o indivíduo ou a comunidade. ${ }^{50}$

A reconstrução de tais práticas no Brasil pode ser um dos caminhos para se entender o concurso dos negros a essas casas rituais, já que buscavam nestes locais a possibilidade de enfrentamento dos males cotidianos, ao mesmo tempo em que elas lhes permitiam reconstruir parte da memória de suas terras de origem. Tal fato pode ser percebido no caso do preto mina Valente José, citado por Leila Algranti. A manipulação de ervas para fins de cura era um costume ritual praticado na África Ocidental, diferenciando, deste modo, as práticas da Costa da Mina das práticas da África Central. ${ }^{51} \mathrm{O}$ tráfico atlântico, desta forma, colocava em contato, no Rio de Janeiro, dois universos rituais distintos que, no contexto do escravismo, iam dando forma à cultura afro-brasileira. As casas configurar-se-iam, portanto, em lugares de circulação de pessoas e culturas em constante diálogo.

Carlos Eugênio Soares, em seu trabalho sobre as Casas de Zungú ou de Angu, permite a reflexão sobre outros exemplos de casas. Segundo o autor, no Rio de Janeiro da primeira metade dos oitocentos, essas casas estavam associa-

\footnotetext{
${ }^{48}$ Leila Mezan Algranti, O feitor ausente: estudos sobre a escravidão urbana no Rio de Janeiro1808-1822, Petrópolis, Vozes, 1988, p. 147.

${ }^{49}$ Laura de Mello e Souza, O Diabo e a Terra de Santa Cru: feitiçaria e religiosidade popular no Brasil colonial, São Paulo, Cia. das Letras, 1989, p. 291; 352-353.

${ }^{50}$ James H. Sweet, op. cit., p. 139-145.

${ }^{51}$ Ibidem, p. 156-157.
} 
das ao batuque, também aos calundus e à alimentação - o consumo do angu. Neste sentido, alimento e sociabilidade estavam profundamente associados, transformando tais casas em lugares de "abastecimento cultural". ${ }^{52}$

A propósito das casas de angu e dos benguelas, uma descrição da Cidade de São Felipe de Benguela, em 1797, fala do consumo do angu ou de algum alimento que lhe era bastante parecido para o narrador:

Estes negros são todos criadores de gados (...) e se sustentam de leite que lhe tiram e deixam coalhar para lhe tirarem a manteiga de que se servem para comer e tratar seus engrenhados cabelos e chamam tal manteiga de Ingunda, e a coalhada que eles chamam Mabala é o seu sustento com o seu Infunda, o qual é feito de farinha de milho e outro mais miúdo chamado Massambala, e outro ainda mais miúdo e muito mal chamado Massangano, que é o que comem os passarinhos, este o moem entre duas pedras e depois fazem ao uma massa que chamam Infunda, ou Quita, e nós portugueses Angu. ${ }^{53}$

Carlos Eugênio Soares faz toda uma discussão em torno da origem do termo angu, a qual não pretendemos aprofundar. Todavia, com base no autor, gostaríamos de destacar que o termo só foi dicionarizado em fins do século XIX, embora já fosse conhecido antes nas ruas do Rio de Janeiro, como demonstram as descrições de Debret ${ }^{54}$ e o nosso informante em passagem por Benguela. Segundo Nei Lopes, a iguaria seria de origem africana, mas de étimo controverso. O autor identifica, tanto na África Ocidental quanto na África Central, termos associados ao milho e a seu preparo que poderiam ter influenciado na definição da palavra angu. Deste modo, prefere acreditar que a palavra é um portuguesismo que sofreu a influência de diversos vocábulos africanos. ${ }^{55}$

Em São João del Rei, na Paragem de Cruz das Almas, Maria Tereza Cardoso encontrou referências, em um processo-crime de 1830, a uma casa que reunia escravos, libertos e livres, e que, segundo as falas senhoriais, era uma "escola de horror e perversidade". Segundo as denúncias, ali ocorriam jogos, batuques, cantarolas, deboches de cachaça e prostituição. Sintomaticamente, o dono desta casa chamava-se Juca Paneleiro, identificado como

${ }^{52}$ Carlos Eugênio Líbano Soares, Zungú: rumor de muitas vozes, Rio de Janeiro, Arquivo Público do Estado do Rio de Janeiro, 1998, p. 26-30.

${ }^{53}$ BN (Biblioteca Nacional do Rio de Janeiro), Notícia da Cidade de São Felipe de Benguela e costumes dos gentios habitantes naquele sertão, 1797, fol. 2.

${ }^{54}$ Carlos Eugênio Líbano Soares, op. cit., p. 31-44.

${ }^{55}$ Nei Lopes, Novo Dicionário Banto do Brasil, Rio de Janeiro, Pallas, 2003. 
"homem branco, pardo ou caboclo". Não encontramos um significado preciso para o termo "paneleiro", mas pensamos em uma possível associação com as vasilhas onde se cozinham os alimentos. ${ }^{56}$

De qualquer forma, o que nos interessa é perceber que a casa dos benguelas, em São João del Rei, pode ter sido um local que também relacionava alimentação e sociabilidade, consumindo-se quem sabe o angu, prato já conhecido pelo grupo na sua região de origem. Dizemos isto, pois nosso informante que visitou a região de Benguela narra outra passagem onde o comer em grupo assume características rituais importantes:

Estes negros criando tanto gado não comem dele a carne e é só para o vender, ou ir criando grande número, em que consiste sua riqueza e ostentação, mas quando qualquer destes ricos morre então matam todo o gado que ele tem e o comem em função nos seus gentílicos funerais, e a memória que lhe conservam há porem em cima da sepultura que há nos caminhos monstruosos todas as caveiras dos bois que comeram bem escarnados com unicamente armações e com o grande número que eles comem fica levantado um grande mausoléu, ou montam de madeira do ar, como eu vi em muitos por todo este sertão (.....57

A presença de elementos africanos nos funerais dos negros no Brasil já foi elemento bem analisado nos trabalhos de Claudia Rodrigues e João Reis. ${ }^{58}$ Portanto, a idéia de que a morte reintegra ao convívio dos ancestrais é motivo de alegria, de dança, de comer; fato que, provavelmente, os benguelas conservaram em sua memória. Chamamos a atenção, no entanto, para o fato de que a casa por eles adquirida poderia também ser um espaço para estas manifestações. Recorrendo às religiões afro-brasileiras, percebe-se um forte simbolismo no comer em grupo na casa de santo. Segundo Raul Lody, a alimentação em conjunto é um importante elemento identitário, pois ajuda na preservação dos costumes, reforçando o vínculo com os deuses e com os antepassados. O próprio preparo dos alimentos, segundo as variadas tradições, é um elemento de reconhecimento étnico. Comer é, portanto, mais do que um ato biológico; constitui-se também em uma prática sociocultural. ${ }^{59}$

\footnotetext{
${ }^{56}$ Maria Tereza Cardoso, Lei Branca e Justiça Negra: crimes de escravos na Comarca do Rio das Mortes (Vilas Del-Rei, 1814-1852), Tese de Doutorado, Campinas, UNICAMP, 2002.

${ }^{57} \mathrm{BN}$, Notícia da Cidade de São Felipe de Benguela e costumes dos gentios habitantes naquele sertão, 1797, fol. 2-3.

${ }^{58}$ Claudia Rodrigues, Lugares dos mortos na cidade dos vivos: tradições e transformações fúnebres no Rio de Janeiro, Rio de Janeiro, Secretaria Municipal de Cultura, 1997, p. 155-164; João José Reis, A morte é uma festa: ritos fúnebres e revolta popular no Brasil do século XIX, São Paulo, Cia. das Letras, 1991, p. 159-162.

${ }^{59}$ Raul Lody, Santo também come, Rio de Janeiro, Pallas, 1998, p. 23-30.
} 
Se como argumentamos acima a constituição da "Nobre Nação" implicava na reconstituição e preservação da memória, através da sufragação dos ancestrais, a casa dos benguelas também poderia ser este lugar do banquete ritual com este propósito. Muitos dos membros da Nobre Nação eram afiliados à Irmandade do Rosário e, nas irmandades, o banquete de confraternização entre os irmãos era uma prática comum, tanto que a própria Igreja tentou controlá-lo, por meio das Constituições do Arcebispado da Bahia, por julgar que neles se imiscuíam em excesso elementos sagrados e profanos. ${ }^{60}$ Neste sentido, mais uma vez, a propriedade da casa pode apontar para esta necessidade de reunião que propiciava um lugar de ritual, de encontro, de louvor aos ancestrais e, conseqüentemente, de reforço da identidade com base em recordações readaptadas a um novo ambiente, apoiando a idéia de vivência e sobrevivência, enfatizada por Sheila Faria, e de abastecimento cultural, indicada por Carlos Eugênio Soares.

Uma segunda questão que está relacionada à aquisição da casa é a idéia de palácio. Esta idéia associada às estruturas políticas do Antigo Regime deve ser considerada, até mesmo para se compreender a busca de prestígio por parte dos benguelas naquela sociedade. Tal fator também teria relação com a própria nomenclatura dos cargos existentes na congregação, como duques e marqueses, componentes da corte e presentes no palácio. Por outro lado, a existência de um reinado e da própria corte implicaria na necessidade do palácio como um local a abrigar os paramentos utilizados quando da realização dos "folguedos", como também a guarda do cofre e dos livros da congregação.

No entanto, a idéia de palácio real também sugere outras relações com as culturas africanas da diáspora. Para as diversas culturas africanas, incluindo as da África Centro-Ocidental, o palácio era o centro político e religioso dos reinos. $\mathrm{Na}$ província do Soyo, no Reino do Congo, era visto como a réplica simbólica do universo. Ritos especiais eram utilizados na sua construção, desde a participação de notáveis especialistas até a escolha e purificação dos materiais que seriam utilizados. Acreditava-se igualmente que a violação da casa nobre poderia trazer infelicidade a toda coletividade. ${ }^{61}$

Em Camarões e no Congo, no século XIX, o palácio, além de abrigar os aposentos do rei e de suas esposas, era onde estavam as sedes das sociedades de máscaras, que desempenhavam um papel político e religioso na estrutura desses

${ }^{60}$ Anderson José M. de Oliveira, "A Festa da Glória. Festas, irmandades e resistência cultural no Rio de Janeiro Imperial", História Social - Revista da Pós-Graduação em História da UNICAMP, Campinas-SP, n. 7, 2000, p. 36-37.

${ }^{61}$ Georges Balandier, La vie quotidienne au Royaume de Kongo du XVI au XVIII siècle, Paris, Hachette, 1965, p. 137-139. 
reinos. Algumas dessas associações congregavam chefes de linhagens e davam-lhes a possibilidade de participar das decisões do rei de acordo com o grau hierárquico assumido. As máscaras, quando usadas, também permitiam a comunicação com os antepassados. Deste modo, a confecção das mesmas implicava numa série de prescrições rituais, obedecendo a determinadas regras e sendo feitas longe dos olhos dos moradores da aldeia. ${ }^{62}$ A propósito, Spix e Martius, quando em viagem ao Tejuco, em 1818, descrevem um cortejo de coroação de reis africanos onde identificam a presença de uma máscara utilizada por um negro:

(...) a banda de música dos pretos, com capinhas vermelhas e roxas, todas rotas, enfeitadas com grandes penas de avestruz, anunciando o regozijo, ao som de pandeiros e chocalhos, de ruidoso canzá e de chorosa marimba; marchava à frente um negro de máscara preta, como mordomo, de sabre em punho; depois os príncipes e princesas, cujas caudas eram levadas por pajens de ambos os sexos; o rei e a rainha do ano antecedente, ainda com cetro e coroa (..... ${ }^{63}$

É bastante provável que o palácio Benguela tenha guardado alguns desses apetrechos. Com relação à mascara, é mais difícil saber, mas os instrumentos musicais, que também tinham caráter sagrado na África, com certeza existiram para o acompanhamento dos "folguedos". Todavia, o que importa perceber é que a possibilidade de recriação de alguns espaços das sociedades de origem foi possível no ambiente escravista. O palácio, desta feita, era um local onde se organizava o poder entre os vivos, mas também destes com os seus ancestrais mortos. Como fica claro, entre os soyos, era a representação cabal do universo e, portanto, do contato entre as duas partes do mesmo. No palácio também se cultuam os ancestrais. Deste modo, a existência da casa dos benguelas também pode cumprir este papel. Jan Vansina fala da existência de templos específicos para os ancestrais entre os povos bantos da África Centro-Ocidental. ${ }^{64}$ Com certeza foram estes mesmos templos que sofreram perseguições dos missionários católicos, a partir do século XVI, sendo por eles incendiados como retrata o Capuchinho Bernardino Inácio da Vezza, em 1750, no Congo. ${ }^{65}$

${ }^{62}$ Peter Junge, "Arte da África", in: . Arte da África, Rio de Janeiro, Centro Cultural Banco do Brasil, 2004, p. 36-38.

${ }^{63}$ J. B. von Spix e C. F. P. Von Martius, Viagem pelo Brasil, Rio de Janeiro, Imprensa Nacional, 1938, apud Marina de Mello e Souza, op. cit., p. 280.

${ }^{64}$ Jan Vansina, Kingdoms of the Savana: a history of Central África states until European occupation, Madison, The University of Wisconsin Press, 1970, p. 32.

${ }^{65}$ James H. Sweet, op. cit., p. 110-111. 
Funcionando como a sede da "Nação Benguela”, o palácio em São João del Rei procurava reorganizar parte dessa memória. Ao fazer isto, permitia ao grupo trabalhar o reforço da sua identidade, criando situações para sua promoção e consagrando espaços de vivência de prestígio para ele. Diferente dos mahis, do Rio de Janeiro, os benguelas não eram minoritários na Irmandade. Todavia, necessitaram de estratégias semelhantes para se auto-afirmarem em meio às disputas dos diferentes grupos étnicos. Com efeito, o tráfico atlântico colocava para os diversos grupos a necessidade de constante atualização das estratégias de sobrevivência. No entanto, como observou Mariza Soares, a instabilidade promovida pelo tráfico era elemento fundamental na constituição das identidades, pois a chegada de novos elementos reatualizava cotidianamente fragmentos das sociedades africanas originais. Igualmente, neste contexto, era importante o culto aos antepassados como forma de manter viva a história da origem do grupo. ${ }^{66}$

\section{Conclusão}

À guisa de conclusão, os resultados apresentados nos indicam a importância de se problematizar não apenas a procedência dos escravos, mas de se caminhar no sentido da busca da compreensão das formas pelas quais identidades se constituíram no cativeiro. Discutir se a escravidão se reproduziu nas Minas e, em especial, em São João del Rei, via tráfico atlântico, crescimento natural ou por uma combinação dos dois mecanismos é importante do ponto de vista da dinâmica econômica daquela sociedade; mas, também o é da perspectiva das experiências de constituição de identidades no cativeiro.

Nesse sentido, pode-se igualmente afirmar que congregações como as dos mahis e dos benguelas foram mais comuns dentro das irmandades do que a historiografia até pouco tempo pensava, demonstrando a importância da realização de pesquisas sobre a temática. Através delas, pode-se complexificar a compreensão dos processos de constituição de identidades étnicas.

Além disso, entendemos que as análises demonstram a relevância de se considerar também o tráfico atlântico para além dos números e do seu impacto econômico. Afinal, a dinâmica do comércio não correspondeu somente à transferência quantitativa de pessoas. Igualmente, pôs em circulação culturas que, recriadas em novo ambiente, deram origem a outras tantas sociedades.

${ }^{66}$ Mariza Soares. "Histórias cruzadas ....", op. cit., p. 151. 